\title{
Public Accounting Firm Switching on the Companies Listed in IDX
}

\author{
Nurul Dwi Setiami ${ }^{\bowtie}$, Badingatus Solikhah \\ Department of Accounting, Faculty of Economics, Universitas Negeri Semarang, Indonesia \\ Gedung L2 Lt. 2 Kampus Sekaran, Gunungpati, Semarang, 50229, Indonesia
}

DOI: http://dx.doi.org/10.15294/jda.v9i1.12007

Received: 1 October 2016. Revised: 20 December 2016. Accepted: 11 February 2017. Published: 31 March 2017

\begin{abstract}
The purpose of this study is to determine the probability of the changes of upgrade, downgrade, and same grade public accounting firms predicted by prior audit opinion, growth rate of the client, public ownership and financial distress. The population in this study is manufacturing companies listed in Indonesia Stock Exchange for year of 2010-2015 which consist of 144 companies. The sampling technique is a purposive sampling method which results for 24 companies. Analysis method uses descriptive statistics and multinomial logistic regression analysis. The results of this study showed that the variables of prior audit opinion, growth rate of client, and financial distress could predict the probability of the changes of upgrade, downgrade and same grade public accounting firms. Meanwhile, public ownership variable could not predict the probability of the changes of upgrade, downgrade and same grade public accounting firms. It can be concluded that to predict the change of public accountant office can be performed by paying attention to prior audit opinion, client's growth rate, and financial distress.
\end{abstract}

Keywords: Prior Audit Opinion; Client Growth Rate; Public Ownership; Financial Distress; KAP Switching

\section{How to cite (APA 6th Style)}

Setiami, D. N. \& Solikhah, B. (2017). Public Accounting Firm Switching on the Companies Listed in IDX. Jurnal Dinamika Akuntansi, 9(1), 23-32.

\section{INTRODUCTION}

According to SFAS number 1 (revised 2013), financial statements are a structured presentation of the financial position and financial performance of an entity. The financial statements of a company are used as a means of decision-making for both internal and external parties. To improve the reliability of financial statements requires external party which are quite expert and free impartial called an independent auditor. Auditors are required to be objective and independence on the information presented by the management of the company in the form of financial statements (Syahtiadi \& Medyawati, 2013). Independence of KAP and auditor will be lost if have long cooperative relationship with client. Jensen and Meckling (1976) argue that agency problem is caused by a conflict of interest and asymmetric information between principle and agent. In agency theory, independent auditors act as a third party between agents and principles that have different interest. Thus, to maintain the independence of auditors, the government issues auditor rotation obligations. The existence of regulation on KAP changes mandatory in Indonesia becomes an interesting thing to be studied. Actually, what factors affect companies in

Nurul Dwi Setiami $(\square)$

E-mail: asetiany@yahoo.com 
Indonesia to change the KAP, especially if the change of KAP occurs outside the provisions of the rules that have been established and how the effect of the regulation of KAP changes mandatory. The change of KAP can be divided into two types, namely mandatory changes (mandatory) and voluntary changes (voluntary) (Febrianto, 2009).

The change of KAP mandatory is a change of KAP due to the obligation of an existing government regulation to make a KAP change / rotation. Meanwhile, the change of KAP voluntary is a change of KAP due to the wishes of a company outside the provisions of government regulations / rules that apply. One of the backgrounds of the government issuing audit rotation obligations is due to the case of Arthur Anderson KAP with his client Enron. The change of KAP voluntary done by many companies in Indonesia. This is proven by the existence of data showing that manufacturing companies listed on the IDX during the year 2010-2015 as many as 144 companies. From the 144 companies, there are 24 companies changed KAP voluntary. Sehingga permasalahan penelitian ini adalah faktor apa saja yang mempengaruhi perusahaan di Indonesia melakukan pergantian KAP. So the problem of this research is what factors affect the company in Indonesia to change the KAP.

A study in British conducted by Hudaib and Coke (2005) shows that these three factors have an effect on the change of KAP. Chadegani, et al., (2011) show that only audit quality which has a significant effect on the auditor switching while the management changes, qualified audit Opinion, client size, financial distress, and audit fee have no significant effect. Damayanti and Sudarma (2007) prove that audit fee has a positive effect and KAP size has a negative effect on the change of KAP in Indonesia. Furthermore, Sinarwati's research (2010) shows that management changes and financial distress affect on the change of KAP, while going concern opinion and auditor's reputation does not affect. Looking at previous research that still shows the diversity of results, it is necessary to investigate further on the factors that encourage companies to change the KAP voluntary.

According to Hermawan \& Fitriany (2013) companies that often change KAP will get a negative view from shareholders. According to Nasser et al., (2006) companies that often change KAP will cause an increase in audit fees. From some of the negative consequences, the company should do a lot of consideration before taking the decision to make KAP changes voluntary. This is due to if the company too often do KAP changes voluntary it will harm the company itself. The change of KAP voluntary can occur due to company / client factor or factor of KAP itself. One of the factors that exist within the company is the possibility of problems between the management of the company (agent) and shareholders (principal) because both are trying to maximize their respective interests (Jensen \& Meckling, 1976). This can happen because of information imbalance (asymmetric information) between agent and principal. A public accountant incorporated in a KAP is a third party that bridges the relationship between agent and principal. Management will make a change of KAP in case of uncertainty over certain accounting practices or policies. The company will look for a KAP that is in line with its accounting reporting and policies (Nagy, 2005).

Clients in order to meet their needs for a good opinion will look for the appropriate auditor in their view and is not closed the possibility to make a change of KAP. KAP changes can be divided into three types that is KAP changes of upgrade, downgrade, and same grade types. Upgrade KAP changes is a change of Medium KAP to Big KAP, from Small KAP to Big KAP, and from Small KAP to Medium KAP. Downgrade KAP changes is a change of Big KAP to Medium KAP, from Big KAP to Small KAP, and from Medium KAP to Small KAP. The change of same grade KAP is a change from Big KAP to the Big KAP, from Medium KAP to Medium KAP, from Small KAP to Small KAP (Hermawan \& Fitriany, 2013).

This study is conducted to determine the probability of upgrade, downgrade and same grade KAP changes predicted with prior audit opinion, client growth rate, public ownership and financial distress. Audit opinion becomes important information for consideration in decision making by the users of financial statements. Client wants auditor to give an unqualified opinion 
on the financial statements (Wiajayani \& Januarti, 2011). If the company receives an opinion other than unqualified, then management will change KAP and look for a more manageable KAP. As businesses continue to grow, demand for KAP that can reduce agency cost and to provide non-audit services is necessary for the expansion of corporate improvements. Therefore, developing business is expected tend to maintain their KAP than their colleagues with lower growth Wijayanti (2010). Companies owned by public are expected to be able to provide better information (Aprillia, 2013), so will use appropriate KAP services. According to Hermawan and Fitriany (2013), financial distress in the company causes the company to change KAP, either a more upgrade, same grade, or downgrade KAP to maintain public trust by reducing audit costs.

Based on the condition that in Indonesia voluntary KAP turnover quite a lot going on and still various research results related to the change of KAP hence interesting research to do with scope of Indonesia. The results of this study are expected to contribute in the economic discipline, to be information on the public accountant profession about the practices of upgrade, downgrade, and same grade KAP changes, and provide insight into the development of auditing especially on the changes of upgrade, downgrade, and same grade KAP.

Agency theory discusses the difference in interest between agents and principals that arise when the information provided by the agent does not match with what is desired by principal. Principal is assumed to be interested only in the financial returns obtained from their investment in the company. Agent is assumed will receive satisfaction not only from the financial compensation they receive but also from the additional involved in the relationship of an agency. In the financial information provider required third party is independent auditor as an intermediary to settle the different of interests in order that information asymmetry that can harm the agent or principal does not occur.

Audit opinion provides useful information for shareholders or other parties concerned with the company. According to Kawijaya and Juniarti (2002), audit opinion other than WTP (unqualified) tends to be less favoured by clients because it can affect shareholder's view on management performance in managing the company. Hudaib and Cooke (2005) find that a company has a tendency to switch its KAP after receiving an audit opinion other than WTP. The company does not tend to switch to higher KAP because the possibility of getting a better opinion will be less because of better auditor quality. The company also does not tend to switch to a same grade KAP because it is unlikely that it will change audit opinion that has been previously obtained. Agency theory assumes that individual acts for his or her own interests (self-interest). If the opinion given by the auditor does not match with the manager, then the manager will make a change of auditors to overcome the problems that exist within the company. So it can be concluded that clients who get an audit opinion other than Unqualified on their financial statements tend to switch to KAP of downgrade type because the company was disappointed and unsatisfied with the opinions given by auditors.

$\mathrm{H}_{1 \mathrm{a}}$ : Companies that receive prior audit opinions other than WTP have a lower probability to switch to KAP of upgrade type than do not switch KAP.

$\mathrm{H}_{1 \mathrm{~b}}$ : Companies that receive prior audit opinions other than WTP have a higher probability to switch to KAP of downgrade type than do not switch KAP.

$\mathrm{H}_{1 c}$ : Companies that receive prior audit opinions other than WTP have a lower probability to switch to KAP of same grade type than do not switch KAP.

Corporate growth rate is a measure of how well the company maintains its economic position both in its industry and in overall economic activity (Copeland et al., 2005). Watts and Zimmerman (1990) argue that as the company grows, the more complex its operations will be, the greater the separation between management and owners. Suparlan \& Andayani (2010) state that the company decides to use a large KAP related to funding, equity or debt needs. According to Suparlan \& Andayani (2010) with the use of additional funds, it requires higher supervision so that investors more trust the company. Joher et al., (2000), states that management requires a more qualified auditor and is able to meet the demands of rapid company growth. If that cannot 
be met, most likely the company will switch the existing auditors.

$\mathrm{H}_{2 \mathrm{a}}$ : Companies with increased growth rate have a higher probability to switch to upgrade type KAP than do not do KAP switching.

$\mathrm{H}_{2 \mathrm{~b}}$ : Companies with increased growth rate have a lower probability to switch to downgrade type KAP than do not do KAP switching.

$\mathrm{H}_{2 \mathrm{c}}$ : Companies with increased growth rate have a lower probability to switch to same grade type KAP than do not do KAP switching.

Companies that have a large proportion of share ownership by the public are considered to be able to provide better disclosure of information (Aprillia, 2013). Sulistiarini \& Sudarno (2012) share ownership by the community results in the public demand for qualified audits, which will encourage companies to switch auditors to qualified KAP.

$\mathrm{H}_{3 \mathrm{a}}$ : Companies with increased level of public ownership have a higher probability to switch to KAP of upgrade type than do not switch KAP.

$\mathrm{H}_{3 \mathrm{~b}}$ : Companies with increased level of public ownership have a lower probability to switch to KAP of downgrade type than do not switch KAP.

$\mathrm{H}_{3}$ : Companies with increased level of public ownership have a lower probability to switch to KAP of same grade type than do not switch KAP.

Financial distress is a condition of companies that are experiencing financial difficulties. There is a strong motivation to switch auditors on companies that are threatened with bankruptcy. Significant financial difficulties affect companies that are threatened with bankruptcy to switch KAP (Schwartz \& Menon, 1985). In addition, Damayanti and Sudarma (2007) state that bankrupt companies more often switch auditors rather than companies that are not bankrupt. According to Wijayanti (2010), the company will choose to switch to smaller KAP to reduce audit costs because the company has been not able to pay the audit fees due to decreased financial capability of the company.

$\mathrm{H}_{4 \mathrm{a}}$ : Companies which are experiencing financial distress have a lower probability to switch to upgrade KAP than do not switch the KAP.

$\mathrm{H}_{4 \mathrm{~b}}$ : Companies which are experiencing financial distress have a higher probability to switch to downgrade KAP than do not switch the KAP.

$\mathrm{H}_{4 \mathrm{c}}$ : Companies which are experiencing financial distress have a lower probability to switch to same grade KAP than do not switch the KAP.

\section{METHODS}

The population in this study is manufacturing companies listed on the Indonesia Stock Exchange 2010-2015 a number of 144 companies. Selection of the sample used purposive sampling method described in table 1 . The criteria determined based on the needs of the research, the company must be listed on the IDX as it must be a company owned by a public that is strict in maintaining stakeholders' trust. Consecutively, it must be registered on the IDX during the study period in order to obtain unbiased data and the company had done KAP switching voluntarily. The method of analysis used in this study is multinomial logistic regression analysis method.

Table 1. The Process of Sample Selection Based on the Criteria

\begin{tabular}{lcc}
\hline Criteria & Not Included in the Criteria & $\Sigma$ \\
\hline Manufacturing companies listed in IDX in 2010-2015 & & 154 \\
Consecutively listed in IDXI in 2010-2015 & $(25)$ & 129 \\
Switching KAP voluntarily & $(68)$ & 61 \\
Publishing financial statement and annual report in & $(35)$ & 26 \\
Rupiah currency during the period 2010-2015 &
\end{tabular}


Total units of analysis

Source : Secondary data, 2016

Variables in this study can be seen in table 2.

Table 2. Measurement of Variables

\begin{tabular}{|c|c|c|}
\hline Variables & Indicator & Measurement \\
\hline $\begin{array}{l}\text { KAP Switch- } \\
\text { ing }\end{array}$ & $\begin{array}{l}\text { KAP switching seen from the size } \\
\text { of its KAP (Hermawan \& Fitriany, } \\
\text { 2013) }\end{array}$ & $\begin{array}{l}\text { Dummy, } \\
0: \text { do not switch KAP } \\
1: \text { upgrade. } \\
2: \text { downgrade. } \\
3: \text { same grade. }\end{array}$ \\
\hline $\begin{array}{l}\text { Prior Audit } \\
\text { Opinion }\end{array}$ & $\begin{array}{l}\text { Prior Audit Opinion measured by } \\
\text { using dummy variable (Chadegani } \\
\text { et al., 2011). }\end{array}$ & $\begin{array}{l}\text { Dummy, } \\
1: \text { unqualified prior audit opinion } \\
\text { with explanatory language, unqualified } \\
\text { opinion, unfair opinions and refuse to } \\
\text { give an opinion } \\
0: \text { unqualified prior audit opinion. }\end{array}$ \\
\hline $\begin{array}{l}\text { Client Growth } \\
\text { Rate }\end{array}$ & $\begin{array}{l}\text { Growth rate is seen based on sales } \\
\text { growth of the company (Nasser } e t \\
\text { al., 2006). }\end{array}$ & x $100 \%$ \\
\hline $\begin{array}{l}\text { Public Own- } \\
\text { ership }\end{array}$ & $\begin{array}{l}\text { Percentage of shares owned by the } \\
\text { public (Aprillia, 2013). }\end{array}$ & $\begin{array}{l}\text { Presented in the table based on the fre- } \\
\text { quency distribution. }\end{array}$ \\
\hline $\begin{array}{l}\text { Financial } \\
\text { Distress }\end{array}$ & $\begin{array}{l}\text { Model of Modification Z “-score } \\
\text { Altman (Ramadhani \& Lukvi- } \\
\text { arman, 2009). }\end{array}$ & $\begin{array}{l}Z^{\prime \prime}=6,56 \mathrm{X} 1+3,26 \mathrm{X} 2+6,72 \mathrm{X} 3+1,05 \\
X 4\end{array}$ \\
\hline
\end{tabular}

\section{RESULTS AND DISCUSSIONS}

The result of multinominal logistic regression on the probability of Upgrade, Downgrade and Same grade KAP switching which was predicted through KAP switching rate, public ownership, financial distress, and prior audit opinion were presented in Table 3 and the results of hypothesis testing were presented in Table 4.

Table 3. Parameter Estimation and its Interpretation

\begin{tabular}{|c|c|c|c|c|c|c|c|c|}
\hline \multirow{2}{*}{ PKAP $^{a}$} & \multirow{2}{*}{ B } & \multirow{2}{*}{$\begin{array}{l}\text { Std. } \\
\text { Error }\end{array}$} & \multirow{2}{*}{ Wald } & \multirow{2}{*}{ Df } & \multirow{2}{*}{ Sig. } & \multirow{2}{*}{$\operatorname{Exp}(B)$} & \multicolumn{2}{|c|}{$\begin{array}{c}\text { 95\% Confidence Inter- } \\
\text { val for } \operatorname{Exp}(\mathrm{B})\end{array}$} \\
\hline & & & & & & & Lower & Upper \\
\hline
\end{tabular}




\begin{tabular}{|c|c|c|c|c|c|c|c|c|}
\hline Intercept & $-2,416$ & ,800 & 9,128 & 1 & ,003 & & & \\
\hline TPK & 1,691 & ,817 & 4,278 & 1 & ,039 & 5,423 & 1,093 & 26,916 \\
\hline $\mathrm{KP}$ & 1,943 & 2,195 & ,784 & 1 & ,376 & 6,982 & ,095 & 515,511 \\
\hline FD &, 052 &, 024 & 4,691 & 1 & ,030 & 1,053 & 1,005 & 1,104 \\
\hline$[\mathrm{OA}=0]$ & $-1,398$ & ,706 & 3,916 & 1 & ,048 &, 247 &, 062 & ,987 \\
\hline$[\mathrm{OA}=1]$ & $0^{\mathrm{b}}$ & . & . & 0 & . & . & . & . \\
\hline Intercept & $-1,149$ & ,690 & 2,772 & 1 & ,096 & & & \\
\hline TPK & 1,842 & ,837 & 4,839 & 1 & ,028 & 6,309 & 1,222 & 32,562 \\
\hline KP & $-2,845$ & 2,507 & 1,288 & 1 & ,256 &, 058 &, 000 & 7,914 \\
\hline $2 \quad \mathrm{FD}$ &, 052 & ,026 & 3,963 & 1 & ,047 & 1,054 & 1,001 & 1,109 \\
\hline$[\mathrm{OA}=0]$ & $-1,942$ & ,739 & 6,906 & 1 & ,009 &, 143 &, 034 & ,610 \\
\hline$[\mathrm{OA}=1]$ & $0^{\mathrm{b}}$ & . & . & 0 & . & . & . & . \\
\hline Intercept & $-2,425$ & ,679 & 12,759 & 1 & ,000 & & & \\
\hline TPK & $-1,902$ & 915 & 4,325 & 1 & ,038 &, 149 &, 025 & ,896 \\
\hline $\mathrm{KP}$ & 2,587 & 1,431 & 3,268 & 1 & ,071 & 13,285 & ,804 & 219,404 \\
\hline FD &,- 011 &, 030 &, 128 & 1 & ,720 & ,989 & ,933 & 1,049 \\
\hline$[\mathrm{OA}=0]$ & 1,132 & ,604 & 3,515 & 1 & 061 & 3,101 & ,950 & 10,126 \\
\hline$[\mathrm{OA}=1]$ & $0^{\mathrm{b}}$ & . & . & 0 & . & . & . & . \\
\hline
\end{tabular}

Source : secondary data, 2016

Table 4. The Result of Hypothesis Test

\begin{tabular}{|c|c|c|c|c|c|c|c|c|c|}
\hline \multirow[b]{2}{*}{ Variable } & \multicolumn{3}{|c|}{ Upgrade } & \multicolumn{3}{|c|}{ Downgrade } & \multicolumn{3}{|c|}{ Same grade } \\
\hline & $\mathrm{H} 1$ & $\begin{array}{l}\text { Re- } \\
\text { sult }\end{array}$ & Kes. & $\mathrm{H} 1$ & $\begin{array}{l}\text { Re- } \\
\text { sult }\end{array}$ & Kes. & $\mathrm{H} 1$ & Result & Kes. \\
\hline $\begin{array}{l}\text { Prior Audit } \\
\text { Opinion }\end{array}$ & $\begin{array}{c}- \\
\text { (sig) }\end{array}$ & $\begin{array}{c}- \\
(\operatorname{sig})\end{array}$ & Accepted & $\begin{array}{c}+ \\
(\operatorname{sig})\end{array}$ & $\begin{array}{c}- \\
(\mathrm{sig})\end{array}$ & Rejected & $\begin{array}{c}- \\
(\mathrm{sig})\end{array}$ & $\begin{array}{c}+ \\
(\mathrm{tdk} \\
\operatorname{sig})\end{array}$ & Rejected \\
\hline $\begin{array}{l}\text { Client } \\
\text { Growth } \\
\text { Rate }\end{array}$ & $\begin{array}{c}+ \\
(\mathrm{sig})\end{array}$ & $\begin{array}{c}+ \\
(\operatorname{sig})\end{array}$ & Accepted & $\begin{array}{c}- \\
\text { (sig) }\end{array}$ & $\begin{array}{c}+ \\
(\mathrm{sig})\end{array}$ & Rejected & $\begin{array}{c}- \\
(\mathrm{sig})\end{array}$ & $\begin{array}{c}- \\
(\mathrm{sig})\end{array}$ & Accepted \\
\hline $\begin{array}{l}\text { Public } \\
\text { Ownership }\end{array}$ & $\begin{array}{c}+ \\
(\mathrm{sig})\end{array}$ & $\begin{array}{c}+ \\
\text { (tdk } \\
\text { sig) }\end{array}$ & Rejected & $\begin{array}{c}- \\
\text { (sig) }\end{array}$ & $\begin{array}{c}- \\
(\mathrm{tdk} \\
\text { sig) }\end{array}$ & Rejected & $\begin{array}{c}- \\
(\operatorname{sig})\end{array}$ & $\begin{array}{c}+ \\
(\mathrm{tdk} \\
\text { sig) }\end{array}$ & Rejected \\
\hline $\begin{array}{l}\text { Financial } \\
\text { Distress }\end{array}$ & $\begin{array}{c}- \\
(\mathrm{sig})\end{array}$ & $\begin{array}{c}+ \\
(\mathrm{sig})\end{array}$ & Rejected & $\begin{array}{c}+ \\
(\operatorname{sig})\end{array}$ & $\begin{array}{c}+ \\
(\mathrm{sig})\end{array}$ & Accepted & $\begin{array}{c}- \\
(\mathrm{sig})\end{array}$ & $\begin{array}{c}- \\
\text { (tdk } \\
\text { sig) }\end{array}$ & Rejected \\
\hline
\end{tabular}

Source : secondary data, 2016

The Probability of Upgrade, Downgrade, and Same grade KAP switching Predicted with Prior Audit Opinion (OA).

$\mathrm{H}_{1 \mathrm{a}}$ stated that companies that receive prior audit opinion other than Unqualified had a lower probability to switch to upgrade KAP than did not switch KAP. $\mathrm{H}_{1 \mathrm{a}}$ was accepted, this study was in line with the result of research conducted by Hermawan and Fitriany (2013) and Hudaib \& Cooke (2005). In the research of Hermawan \& Fitriany (2013) revealed that if the company switched to upgrade KAP when receiving unqualified prior audit opinion was feared could lead 
to a lack of possibility to get a unqualified opinion because of better audit quality considerations. This opinion was in line with the agency theory which assumed that all individuals acted for their own interests (self interest). If the opinion given by the auditor was not in accordance with management's wishes, then management would feel the need to make a change of KAP to overcome the problems that existed within the company.

$\mathrm{H}_{1 \mathrm{~b}}$ stated that companies that received prior audit opinion other than unqualified had a higher probability to switch to downgrade KAP than did not switch KAP. $\mathrm{H}_{1 \mathrm{~b}}$ was rejected, this research was in line with research conducted by Sihombing and Laksito (2012), Pratini and Astika (2013), Juliantari and Rasmini (2013). The agency theory assumed that the auditor was a third party bridging the relationship between agent and principal (Jensen \& Meckling, 1976). Auditors assigned to audit the financial statements of the company would give an audit opinion on the fairness of the financial statements. The principals wanted unqualified opinion for their financial statements. If the company did not get an unqualified opinion, then the principal judged that the agent did not work as he wished, and the principal assessed the company in bad condition. Changes of downgrade KAP was feared to cause a negative assumption from users of financial statements on the quality of financial statement owned by the company (Aprillia, 2013).

$\mathrm{H}_{1 \mathrm{c}}$ stated that companies, which received prior audit opinion other than unqualified, had a lower probability of switching to a same grade KAP than did not switch KAP. $\mathrm{H}_{1 \mathrm{c}}$ was rejected, this research was in line with research conducted by Kawijaya and Janiarti (2002), Damayanti and Sudarma (2007), Sihombing and Laksito (2012). The agency theory assumed that the auditor was a third party bridging the relationship between agent and principal (Jensen \& Meckling, 1976). Auditors assigned to audit the financial statements of the company would give an audit opinion on the fairness of the financial statements. The principal wanted the unqualified opinion for the financial statements. If the company did not get an unqualified opinion, then the principal judged that the agent did not work as he wished, and the principal assessed the company in bad condition. This could also be caused if the company switched to KAP when receiving prior audit opinion other than unqualified, the company would get negative response from market participants, because the company was considered to conduct opinion shopping (Hermawan \& Fitriany, 2013).

\section{The Probability of Switching Upgrade, Downgrade, and Same grade KAP Predicted with Client Growth Rate (TPK).}

$\mathrm{H}_{2 \mathrm{a}}$ stated that companies with increased growth rate had a higher probability of switching to upgrade KAP than did not switch the KAP. $\mathrm{H}_{2 \mathrm{a}}$ was accepted, it was in line with research conducted by Syahtiadi and Medyawati (2012). Increased corporate growth can lead to KAP switching. As the company grew, the more complex its operations were, the more the separation between management and owners, so the demand for auditor independence increased to reduce agency costs (Watts \& Zimmerman, 1990). In addition, companies with high growth rate would be able to rent larger KAP than before. Changes into a larger KAP could improve the quality of the corporate financial statements in order to attract investors to invest.

$\mathrm{H}_{2 \mathrm{~b}}$ stated that companies with increased growth rates had a lower probability of switching to downgrade KAP than did not switch the KAP. $\mathrm{H}_{2 \mathrm{~b}}$ was rejected, the study was in line with research conducted by Sihombing and Laksito (2012), Nasser et al. (2006), Wijayanti (2010), Nuryanti (2012). Nasser et al. (2006) argued that companies with large growth seen in terms of sales, was not a consideration in making a change of KAP. The old KAP has supported the corporate policy in maximizing its profits, so by not changing the KAP, the company was more effectively maximizing its profits. In addition, the company did not need to bear new costs that could affect corporate growth of the client companies due to KAP switching (Hermawan \& Fitriany 2013).

$\mathrm{H}_{2 \mathrm{c}}$ stated that companies with increased growth rate had a lower probability of switching to a same grade KAP than do not switch the KAP. $\mathrm{H}_{2 c}$ was accepted, the study was in line with 
research conducted by Hermawan and Fitriany (2013). This result showed that with high client growth rate, companies would be able to rent reputable or equivalent KAP that was considered capable of fulfilling their desires. As the company grew, the more complex its operations would be, the greater the separation between management and owners, so the demand for auditor independence increased to reduce agency costs (Watts \& Zimmerman, 1990).

\section{The Probability of Upgrade, Downgrade, and Same grade KAP Switching Predicted with Public Owner (KP).}

$\mathrm{H}_{3 \mathrm{a}}$ stated that companies with increasing level of public ownership had a higher probability of switching to upgrade KAP than did not switch the KAP. H3a was rejected, this study was in line with research conducted by Aprillia (2013). Based on the table of frequency distribution which showed that the manufacturing companies being sample were dominated by the companies with the percentage of public share below $50 \%$. So the manufacturing companies did not want to make a change of upgrade KAP voluntarily. Cenker's research (2008) in Suparlan and Andayani (2010) stated that client characteristics influenced a company's decision to replace or maintain a KAP.

$\mathrm{H}_{3 \mathrm{~b}}$ stated that companies with increasing level of public ownership had a lower probability of switching to a downgrade KAP than did not switch the KAP. $\mathrm{H}_{3 \mathrm{~b}}$ was rejected, this study was in line with research conducted by Aprillia (2013). Research of Guedhami et al. (2009) in Suparlan and Andayani (2010) found that spreading share ownership had an important effect to obtain high qualified financial statements embodied in the selection of auditors from qualified KAP. Based on the frequency distribution table which showed that the manufacturing companies being the sample were dominated by the companies with the percentage of public share below $50 \%$. So this study could not prove that the effect of high level of public ownership had a lower probability of switching to a downgrade KAP.

$\mathrm{H}_{3 c}$ stated that companies with increasing level of public ownership had a lower probability of switching to a same grade KAP than did not switch the KAP. $\mathrm{H}_{3 \mathrm{c}}$ was rejected, this research was in line with research conducted by Sulistiarini and Sudarno (2012). The result of this study indicated that spreading share ownership was not the main factor for the company to switch KAP. This indicated that the company would still maintain KAP which audited previously. Herusetya (2008) mentioned concentrated ownership would dominate minority shareholders, it showed that the higher shareholders by the public was pushing to make decisions that did not harm all shareholders.

\section{The Probability of Upgrade, Downgrade, and Same grade KAP Switching Predicted through Financial Distress (FINDIS).}

$\mathrm{H}_{4 \mathrm{a}}$ stated that companies, which experienced financial distress, had a lower probability to switch to upgrade KAP than did not switch KAP. $\mathrm{H}_{4 \mathrm{a}}$ was rejected, this study supported research conducted by Pratitis (2012), Sulistiarini and Sudarno (2012). This happened because most of the companies sampled in this study used the services of medium and small KAP, so the companies assumed that by switching the KAP would require a big cost, especially if the company switched to a large KAP that could make the financial condition of the company decreased.

$\mathrm{H}_{4 \mathrm{~b}}$ stated that companies which experienced financial distress had a higher probability to switch to a downgrade KAP than did not do the change of KAP. $\mathrm{H}_{4 \mathrm{~b}}$ was accepted, this research was in line with research conducted by Hermawan and Fitriany (2013). This meant that companies in a distress condition would switch to smaller KAP than before. Because by switching to a smaller $\mathrm{KAP}$, the audit costs incurred by the company were not too expensive.

$\mathrm{H}_{4 \mathrm{c}}$ stated that companies which experienced financial distress had a lower probability to switch to same grade KAP than did not switch the KAP. H4c was rejected, this research supported research conducted by Sulistiarini and Sudarno (2012). The result of this study indicated that financial difficulties would not be a consideration for the company to switch KAP. Auditors who were insolvent and experiencing unhealthy financial position were more likely to bind their 
auditors to maintain the trust of shareholders and creditors and reduce the risk of litigation (Nasser et al., 2006).

The companies in conducting the examination engagement followed the rules set by the regulatory agency. In the past, KAP changes were required periodically, but currently there is no obligation to change KAP but it must be within 5 years of replacing the auditor which performing the field task. This regulatory change allowed companies to not change the KAP, but this study showed that the probability of KAP switching remained large depended on the interests of each company.

\section{CONCLUSIONS}

The results of this study indicate that prior audit opinion other than unqualified (WTP) can predict the probability of upgrade KAP changes, while the probability of downgrade and same grade KAP changes cannot be predicted by the variable of prior audit opinion. Growth rate of clients can predict the probability of upgrade and same grade KAP changes, while the probability of downgrade KAP changes cannot be predicted by the client's growth rate variable. Public ownership cannot predict the probability of upgrade, downgrade and same grade KAP changes. Financial distress can predict the probability of downgrade KAP changes, while the probability of upgrade and same grade changes cannot be predicted by financial distress variable.

It is suggested to add variables that may affect upgrade, downgrade, and same grade KAP changes such as profitability, audit delay, firm size and so on, to get different results. The sample in this study is manufacturing companies listed on the IDX, for further research can use companies such as banking, or property and real estate. The variable of clients' growth rate used the proxy of sales difference, to describe the growth rate of clients there are other proxies such as the amount of assets and equity that can be used to allow for different results. KAP rating update needs to be done to know the development of KAP in Indonesia every year.

\section{REFERENCES}

Aprillia, E. (2013). Analisis Faktor-Faktor yang Mempengaruhi Auditor Switching. Accounting Analysis Journal, 2(2).

Beisland, L. A., Mersland, R., \& Strøm, R. Ø. (2015). Audit Quality and Corporate Governance: Evidence from the Microfinance Industry. International Journal of Auditing, 19(3), 218-237.

Causholli, M., \& Knechel, W. R. (2012). Lending Relationships, Auditor Quality and Debt Costs. Managerial Auditing Journal, 27(6), 550-572.

Chadegani, A. A., Mohamed, M. Z., \& Jari, A. (2011). The Determinant Factors of Auditor Switch Among Companies Listed on Tehran Stock Exchange. International Research Journal of Finance and Economics, 80(1), 158-169.

Copeland, T. E., Weston, J. F., \& Shastri, K. (2005). Financial Theory and Corporate Policy. Massachusetts: Addison-Wesley Boston.

Damayanti, S., \& Sudarma, M. (2007). Faktor-Faktor yang Mempengaruhi Perusahaan Berpindah Kantor Akuntan Publik. Simposium Nasional Akuntansi, 11, 1-50.

Hermawan, Y. D. \& F. (2013). Analisis Faktor-Faktor yang Mempengaruhi Pergantian Kantor Akuntan Publik Upgrade, Downgrade, dan Same grade pada Perusahaan yang Terdaftar di Bursa Efek Indonesia (BEI). Accounting Analysis Journal, 2(2).

Herusetya, A., \& Puspita, E. (2008). Determinan Pemilihan Auditor The Big 4 Di Indonesia oleh Perusahaan Publik. Jurnal Akuntansi dan Keuangan, 2(3), 467-486.

Hudaib, M., \& Cooke, T. E. (2005). Qualified audit opinions and auditor switching. United Kingdom: Department of Accounting and Finance School of Business and Economics University of Exeter.

Jensen, M. C., \& Meckling, W. H. (1976). Theory of the Firm: Managerial Behavior, Agency Costs and Ownership Structure. Journal of Financial Economics, 3(4), 305-360.

Joher, H., Ali, M., Shamsher, M., Annuar, M., \& Ariff, M. (2000). Auditor Switch Decision of Malaysian Listed Finns: Tests of Determinants and Wealth Effect. Pertanika J. Soc. Sci. \& Hum, 8(2), 77-90. 
Juliantari, N. W. A., \& Rasmini, N. K. (2013). Auditor Switching dan Faktor-Faktor yang Mempengaruhinya. E-Jurnal Akuntansi, 231-246.

Juniarti, J., \& Kawijaya, N. (2004). Faktor-Faktor yang Mendorong Perpindahan Auditor (Auditor Switch) pada Perusahaan-Perusahaan di Surabaya dan Sidoarjo. Jurnal Akuntansi dan Keuangan, 4(2), 93104.

Kuo, L. C., Lin, C. J., \& Lin, H. L. (2016). Auditor switch decisions under forced auditor change: evidence from China. Asian Review of Accounting, 24(1), 69-89.

Lennox, C. S., \& Pittman, J. A. (2011). Voluntary Audits Versus Mandatory Audits. The Accounting Review, 86(5), 1655-1678.

Nasser, T. A. A., Wahid, A. E., Nazri, N. S. F. M. S., \& Hudaib, M. (2006). Auditor-Client Relationship: the Case of Audit Tenure and Auditor Switching in Malaysia. Managerial Auditing Journal, 21(7), 724-737.

Nuryanti, L. (2012). Pengaruh Opini Audit dan Tingkat Pertumbuhan Perusahaan Terhadap Pergantian Auditor. Kumpulan Riset Universitas Negeri Surabaya.

Pratini, I. G. A. A., \& Astika, I. B. P. (2013). Fenomena Pergantian Auditor di Bursa Efek Indonesia. E-Jurnal Akuntansi, 470-486.

Pratitis, Y. T. (2012). Auditor Switching: Analisis Berdasar Ukuran KAP, Ukuran Klien dan Financial Distress. Accounting Analysis Journal, 1(1).

Rusmin, R., Rusmin, R., Evans, J., \& Evans, J. (2017). Audit quality and audit report lag: case of Indonesian listed companies. Asian Review of Accounting, 25(2), 191-210.

Salehi, M., \& Alinya, A. A. (2017). Relationship between corporate governance and audit switching: Iranian evidence. International Journal of Law and Management, 59(5), 673-686.

Schneider, A. (2017). Is Commercial Lending Affected by Knowledge of Auditor Switches from Big 4 Firms to Regional Firms? Accounting Research Journal, 30(2).

Sihombing, M. M. (2012). Analisis Hubungan Auditor-Klien: Faktor-Faktor yang Mempengaruhi Auditor Switchin. Semarang: Diponegoro University.

Sudarno, E. S. (2012). Analisis Faktor-Faktor Pergantian Kantor Akuntan Publik. Diponegoro Journal of Accounting, 1(2), 1-12.

Suparlan, \& Andayani, W. (2010). Analisis Empiris Pergantian Kantor Akuntan Publik Setelah Ada Kewajiban Rotasi Audit. In Simposium Nasional Akuntansi XIII (pp. 1-25).

Syahtiadi, F. (2012). Analisis Hubungan Auditor-Klien: Faktor-Faktor yang Mempengaruhi Auditor Switching di Indonesia (Studi Empiris pada Perusahaan Property and Real Estate yang Terdaftar di $B E I)$. Gunadharman University.

Watts, R. L., \& Zimmerman, J. L. (1990). Positive accounting theory: a ten year perspective. Accounting review, 131-156.

Weiss, R., \& Kalbers, L. (2013). Determinants of auditor changes for non-accelerated filers. Research in Accounting Regulation, 25(1), 13-29.

Wijayanti, M. P. (2010). Analisis Hubungan Auditor-Klien: Faktor-Faktor Yang Mempengaruhi Auditor Switching Di Indonesia. Semarang: Diponegoro University. 